\title{
Carcass parameters of santa inês/dorper lambs fed with live yeast concentrate
}

\begin{abstract}
The quality of the sheep meat directly affects its demand, and nutrition was the factor that most influenced the quality of the carcasses. This study evaluated the addition of Live Yeast Concentrate (LYC) in the diet of Santa Ines/Dorper lambs and the effects on carcass characteristics of 16 non-castrated weaned male animals at two treatments (Yeast and control). Only the group Yeast received $2 \mathrm{~g}$ of LYC/animal day. The animals were slaughtered after electrical shock and the carcasses were divided into six sections as follows: leg, loin, shoulder, loin, rib and neck. Carcass quality parameters were evaluated. The inclusion of LYC on lamb's diet affected both parameters carcass weight and size of the animals as well as the commercial cuts weight, but showed no effect on neither yield whole carcass nor commercial cuts. Regarding Loin Eye Area (LEA) and fat thickness (FT) the group LYC had significantly higher results (respectively $14.0 \mathrm{~cm} 2$ LEA and $1.7 \mathrm{~mm}$ FTx $13.0 \mathrm{~cm} 2$ and $1,2 \mathrm{~mm}$ for group LYC and Control). It was concluded that inclusion of LYC on diet can be a good alternative to improve the parameters FT and LEA.
\end{abstract}

Keywords: carcass, feed additive, lambs, yeast, parameters, cover thickness, shoulder, carcass weight, Carcass quality parameters, yeast concentrate, anatomical region, geographical region, racial types, slaughter, Petropolis
Volume 2 Issue 2 - 2018

\author{
Aronovich M,' Miranda ZB, ${ }^{2}$ Perali C, ${ }^{3}$ de \\ Andrade AN, ${ }^{4}$ Eliane Rodrigues, ' Cabral \\ Neto $O,{ }^{4}$ Rosa $C A R^{5,6}$ \\ 'Agricultural Research Company of Rio de Janeiro State, Brazil \\ ${ }^{2}$ Fluminense Federal University, Rio de Janeiro, Brazil \\ ${ }^{3}$ Castelo Branco University. Rio de Janeiro, Brazil \\ ${ }^{4}$ Technical Director of LFA Feed Additives, Lesaffre Group Rio \\ de Janeiro, Brazil. \\ ${ }^{5}$ Federal University Rural of Rio de Janeiro. Rio de Janeiro, Brazil \\ ${ }^{6}$ Member of Conselho Nacional de Desenvolvimento Científico \\ e Tecnologico, Brazil
}

Correspondence: Carlos Albertoda Rocha Rosa, Titular Pleno de Micologia e Micotoxicologia, Federal University Rural of Rio de Janeiro, Rio de Janeiro, Brazil, Email shalako1953@gmail.com

Received: December 20, 2017| Published: April 25, 2018
Abbreviations: LYC, live yeast concentrate; LEA, loin eye area; FT, fat thickness; LL, leg length; CL, carcass length; RT, round thickness; HCW, hot carcass weight; CCW, cold carcass weight; ICL, in cooling losses; HCY, hot carcass yield; $\mathrm{CD}$, chest depth; FCT, fat cover thickness

\section{Introduction}

Sheep's meat consumption in Brazil is still affected by the quality of the product offered to consumers. Generally, the products offered are from older animals with low quality carcass and components. ${ }^{1}$ Thus, to devise an efficient meat production system, carcass quantitative and qualitative characteristics are major goals once directly affecting meat quality. ${ }^{2}$ According to, ${ }^{3}$ carcass quality in sheep depends on several factors related to animal and environment. Nutrition is one of the most important factors that will define the quality of carcass and its components. Studying carcasses allows evaluation of parameters related to objective and subjective measures of the aspects and attributes inherent to the edible portion. ${ }^{4}$ Those measures allow comparisons between racial types, live and/or slaughter weights and feeding systems, however, all the techniques involved in animal breeding must converge to the ultimate goal of obtaining a better carcass in less time. ${ }^{5,6}$ affirm that quantitative evaluation of carcass is based on anatomical region composition and histological tissue composition of the carcass. Anatomical region composition is based on standard cuts, enabling better characterization in consumers market. Tissue composition is based on the amount of muscle, adipose and bone tissues on the carcass. The type of standard cut varies according to geographical region since it is related to culinary traditions. ${ }^{7}$ The standardization and nomenclature of cuts vary widely between countries and even between states or region within a country, which makes it often confusing. ${ }^{8}$ Present paper intends to contribute with knowledge of using natural food products that may provide a better quality, yield and uniformity of sheep carcass without jeopardizing animal and human health.

\section{Materials and methods}

An experiment was performed using 16 weaned lambs, half blood Santa Ines/Dorper, at Greenlamb Farm, Araruama County, Rio de Janeiro State, Brazil. The weaning lambs were randomly divided in 2 groups of 8 animals each (T0 - control and T1 - Yeast). The trial lasted five months, when the animals were confined getting the same sanitary and feed management (diet is described in Table 1). The T1 group animals received $2 \mathrm{~g}$ daily of Biosaf ${ }^{\mathbb{B}}$ commercial product constituted by $10 \times 10^{9} \mathrm{CFU} / \mathrm{g}$ live yeast cells of Saccharomyces cerevisiae strain Sc47 (LYC). Treatments were arranged in a completely randomized design with eight replications and analyzed according to the model:

Yij $=\mathrm{m}+\mathrm{Ti}+\mathrm{eij}$, where: $\mathrm{Yij}=\mathrm{observation}$ for animal $\mathrm{j}$ receiving treatment $\mathrm{i}, \mathrm{m}=$ overall constant; $\mathrm{Ti}=$ effect of treatment $\mathrm{i}$, eij=random error to each observation.

The animals were slaughtered at the authorized slaughterhouse FARMING at Petropolis, Rio de Janeiro State. The animals were slaughtered after electrical shock with equipment capable of producing at the output 300 Volts direct current of 1.5 Amperes and brought to bleed. After evisceration, viscera were emptied, washed and weighed. The carcasses were weighed to obtain the hot carcass weight and divided by the spine resulting in two half-carcasses. After $24 \mathrm{~h}$, they were reweighed to obtain the weight of cold carcass. After cooling, the carcasses were divided into the standard cuts, described below:

I. Neck - Understands the seven cervical vertebrae;

II. Ribs - Cut between the sixth rib and the last lumbar vertebra. The ribs were cut to approximately $8 \mathrm{~cm}$ from the edge of the column; 
III. loin - cut between the first and sixth lumbar vertebrae;

IV. Palette - Obtained by disarticulation of the scapula;

V. Sidecut - Cut between the first and thirteenth thoracic vertebra;

VI. Leg - Cut between the last lumbar and first sacral vertebra;

Objective measurements were taken directly on the carcasses and were conducted according to the methodology ${ }^{9}$ and can be described as follows:

I. Carcass Length (CL): Obtained by using tape: from the front edge of the pubic bone to the joint of the last cervical vertebra with first rib;

II. Leg Length (LL): Obtained by using metallic tape for direct reading: from the front edge of the pubic bone to the midpoint of the joint of the tarsal bones;

III. Round Thickness (RT): Obtained by using a metal tape measure for direct reading, placed horizontally above the pubic bone;

IV. Hot Carcass Weight (HCW): Obtained through direct weighing of the still warm carcass after removal of the hide, head, feet and viscera;

V. Cold Carcass Weight: (CCW) produced by direct weighing the carcass after 24 hours in a cold chamber;

VI. In Cooling Losses (ICL): Obtained by difference between the weight of the hot carcass and cold carcass weight;

VII. Hot Carcass Yield (HCY): Obtained by the ratio of hot carcass weight and live weight;

VIII. Palette Yield (PY): Obtained by the ratio between the weight of the palette and hot carcass weight;

IX. Shank Yield (SY): Obtained by the ratio between the weight of the ham and hot carcass weight;

X. Loin Yield (LY): Obtained by the ratio between the weight of the loin and hot carcass weight;

XI. Sidecut Yield ( $\mathrm{ScY})$ : Obtained by the ratio between the weight of the ribs and hot carcass weight;

XII. Carré Yield (CY): Obtained by the ratio between the weight of the loin and hot carcass weight;

XIII. Neck Yield (NY): Obtained by the ratio between the weight of the neck and hot carcass weight;

XIV. Carcass Compactness Index (CCI): Obtained by the ratio between the length of the carcass and cold carcass weight;

XV. Chest Depth (CD): Measurement with a compass metal spikes, placed between the spine and sternum in the region of crosses at maximum distance. Measuring the opening of the compass;

XVI. Chest Width (CW): Direct measurement of the greatest distance between the right and left ribs, obtained by metallic tape;

XVII. Ramp Perimeter (RP): Measured with a tape with reference to the trochanter of both femurs;

XVIII. Ramp Width (RW): Measured with the aid of a compass metal spike placed on the lateral and medial side of the upper portion of the leg. Measuring the opening of the compass;

For the following parameters, it was used the methodology described by, adapted by,$^{10}$ using the checkered plastic ruler in $\mathrm{cm}^{2}$ produced by the Institute of Animal Science of Nova Odessa:

I. Ribeye Area (RA): direct measurement at the face of the $12^{\text {th }}$ rib;

II. Fat Cover Thickness (FCT): Obtained as the mean value taken at three points of the face of the $12^{\text {th }}$ rib.

Table I Characteristic of lamb carcasses fed with and without LYC

\begin{tabular}{|c|c|c|c|}
\hline \multirow[t]{2}{*}{ Parameter } & \multicolumn{2}{|c|}{ Tratament } & \multirow[t]{2}{*}{ Average } \\
\hline & With LYC & Without LYC & \\
\hline $\begin{array}{l}\text { Average Live Weight } \\
\text { before transport }(\mathrm{kg})\end{array}$ & $34,7 \pm 2,31^{\mathrm{a}}$ & $32,8 \pm 1,97^{\mathrm{b}}$ & 33,8 \\
\hline $\begin{array}{l}\text { Average Live Weight at } \\
\text { slaughterhouse }(\mathrm{kg})\end{array}$ & $33,7 \pm 4,33^{\mathrm{a}}$ & $32,3 \pm 3,98^{\mathrm{b}}$ & 33,0 \\
\hline Hot Carcass Weight (kg) & $15,7 \pm 0,58^{\mathrm{a}}$ & $14,4 \pm 0,88^{\mathrm{b}}$ & 15,1 \\
\hline Cold Carcass Weight (kg) & $15,3 \pm 2,35^{\mathrm{a}}$ & $14,0 \pm 2,62^{\mathrm{b}}$ & 14,7 \\
\hline Hot Carcass Yield (\%) & $48,9 \pm 3,15^{\mathrm{a}}$ & $46,3 \pm 6,24^{b}$ & 47,6 \\
\hline In Cooling Losses (\%) & $2,6 \pm 0,30^{\mathrm{a}}$ & $2,5 \pm 0,31^{\mathrm{a}}$ & 2,5 \\
\hline $\begin{array}{l}\text { Carcass Compactness } \\
\text { Index }\end{array}$ & $0,26 \pm 0,09^{\mathrm{a}}$ & $0,25 \pm 0,08^{\mathrm{a}}$ & 0,25 \\
\hline Rib eye Area (cm2) & $14,0 \pm 0,90^{\mathrm{a}}$ & $13,0 \pm 1,17^{\mathrm{b}}$ & 13,5 \\
\hline $\begin{array}{l}\text { Fat Cover Thickness } \\
(\mathrm{mm})\end{array}$ & $1,7 \pm 0,12^{\mathrm{a}}$ & $1,2 \pm 0,14^{\mathrm{b}}$ & 1,45 \\
\hline
\end{tabular}

Means followed by the same letter do not differ by Wilcoxon test $(p>0,05)$

\section{Results and discussion}

The data obtained for characteristics of carcasses are presented on Table 1. Animals in the Yeast group were slaughtered at heavier weights and therefore greater $\mathrm{HCW}(15.7 \mathrm{~kg}$ and $14.4 \mathrm{~kg}$, respectively Yeast and Control group) and CCW (15.3kg and 14.0kg). Similar data were obtained by ${ }^{11}$ using half-blood Dorper castrated males evaluating four levels of supplementation with concentrates and three types of oil in grazing animals, having obtained the highest values of HCW $(14.66 \mathrm{~kg})$ in the treatment $30 \%$ sunflower oil. The carcass yield (CY) data also showed higher values to the Yeast group (48.9\% and $46.3 \%$ respectively for Yeast and control groups). CY data obtained by showed lower values (42.4\%), probably due to the use of purebred Santa Ines animals, which characteristically present carcass conformation of lower quality than other breeds ${ }^{11}$ also found a lower value $(44.38 \%)$ even in the treatment of best result $(30 \%$ sunflower oil). Evaluating rib eye area (RA) data, it also showed superiority of Yeast group $\left(14.0 \mathrm{~cm}^{2}\right)$ when compared to control group $\left(13.0 \mathrm{~cm}^{2}\right)$, similarly to those obtained by ${ }^{12}$ who found results ranging from 11.0 to $13.0 \mathrm{~cm}^{2}$ with crossbred lambs Bergamácia and Corriedale receiving diets with four different preserved corn grains. The Carcass Compactness Index $(\mathrm{CCI})$ values $(0.26$ and 0.25 , respectively Yeast and control group) and In Cooling Losses (ICL) (2.6\% and 2.5\%) obtained in this study showed no significant difference by Wilcoxon test, being similar to ${ }^{13}$ who found values of ICL $(2.26 \%)$ and CCI $(0.20)$ for Santa Inês animals fed diets with different energy levels. The yields of retail cuts are shown in Table 2. The data showed no statistical difference between yields of the standard cuts. ${ }^{14}$ found 
similar yield data for leg and shoulder of crossbred Dorper Sheep with Santa Inês, slaughtered at an average weight of $30 \mathrm{~kg}$. The data from morphometric or objective measures are shown in Table 3. The following parameters Carcass Length (CL), Leg Length (LL), Round Thickness (RT) and Ramp Perimeter (RP) were higher for the group of animals that received $2 \mathrm{~g} \mathrm{LYC}$, while the Ramp Width (RW) parameter was not influenced. This data corroborate those obtained by ${ }^{14}$ when testing lambs cross of Santa InêsxDorper $(\mathrm{CL}=60.4 \mathrm{~cm}$ and $\mathrm{LL}=37.0 \mathrm{~cm}$ ) slaughtered at $29.9 \mathrm{kgLW}$. The data found at present work suggested that the addition of LYC have positively influenced the animal size (live weight) at slaughter and carcass characteristic measures in standard cuts yield. ${ }^{15}$

Table 2 Commercial cuts: ham, shoulder, loin, rib, loin and neck in lambs fed with and without LYC

\begin{tabular}{llll}
\hline Parameter & $\begin{array}{c}\text { Tratament } \\
\text { With LYC }\end{array}$ & Without LYC & Average \\
\hline Palette Yield (\%) & $31,19 \pm 5,49^{\mathrm{a}}$ & $30,98 \pm 3,11^{\mathrm{a}}$ & 31,09 \\
Shank Yield (\%) & $21,53 \pm 1,54^{\mathrm{a}}$ & $21,83 \pm 1,76^{\mathrm{a}}$ & 21,68 \\
Loin Yield (\%) & $6,87 \pm 0,55^{\mathrm{a}}$ & $6,91 \pm 1,08^{\mathrm{a}}$ & 6,89 \\
Sidecut Yield (\%) & $19,77 \pm 1,32^{\mathrm{a}}$ & $18,58 \pm 1,80^{\mathrm{a}}$ & 19,18 \\
Carré Yield (\%) & $13,37 \pm 1,95^{\mathrm{a}}$ & $13,95 \pm 2,02^{\mathrm{a}}$ & 13,66 \\
Neck Yield (\%) & $7,27 \pm 0,60^{\mathrm{a}}$ & $7,75 \pm 0,53^{\mathrm{a}}$ & 7,51 \\
\hline
\end{tabular}

Means followed by the same letter do not differ by Wilcoxon test $(p>0,05)$

Table 3 Objective measures of lambs fed with and without LYC

\begin{tabular}{llll}
\hline Parameter & $\begin{array}{c}\text { Treatament } \\
\text { with LYC }\end{array}$ & Average \\
& without LYC & \\
\hline Carcass Length (cm) & $61,20 \pm 3,34^{\mathrm{a}}$ & $58,70 \pm 3,87^{\mathrm{b}}$ & 59,95 \\
Leg Length (cm) & $36,50 \pm 3,74^{\mathrm{a}}$ & $34,90 \pm 3,80^{\mathrm{b}}$ & 35,70 \\
Round Thickness (cm) & $8,30 \pm 0,62^{\mathrm{a}}$ & $7,00 \pm 0,79^{\mathrm{b}}$ & 7,65 \\
Chest Depth (cm) & $26,70 \pm 2,83^{\mathrm{a}}$ & $25,80 \pm 4,30^{\mathrm{a}}$ & 26,25 \\
Ramp Perimeter (cm) & $67,80 \pm 1,90^{\mathrm{a}}$ & $66,30 \pm 2,35^{\mathrm{b}}$ & 67,05 \\
Ramp Width (cm) & $30,10 \pm 5,55^{\mathrm{a}}$ & $29,00 \pm 3,48^{\mathrm{a}}$ & 29,55 \\
\hline
\end{tabular}

Means followed by the same letter do not differ by Wilcoxon test $(p>0,05)$

\section{Conclusion}

The inclusion of LYC on sheep diet has positive influence on weight and size parameters of the animals as well as its standard cuts, but has no effect on neither whole carcass nor standard cuts. The inclusion of LYC on lamb's diet positively affects ribeye area and fat cover parameters.

\section{Acknowledgements}

None.

\section{Conflicts of interest}

The authors declare there is no any conflict of interest.

\section{References}

1. Furosho Garcia IF, Perez JRO, De Oliveira MV. Carcass characteristics of Texel X Bergamacia, Texel X Santa Inês and pure Santa Inês lambs, finished in confinement with coffee hull as a part of the diet. Brazilian Journal of Animal Science. 2000;29(1):253-260.

2. Silva NV, Da JHV, Da Silva, et al. Characteristics of sheep carcass and meat: a review of methodology and factors of influence. Acta Veterinaria Brasilica. 2008;2(4):103-110.

3. Furosho Garcia IF, Perez JRO, Bonagurio S, et al. Alometric study of cuts and tissues of the carcass of purebred and crossbred Santa Inês lambs. Brazilian Journal of Animal Science. 2006;35(4):1416-1422.

4. Santos C L, Pérez JRO. Standard cuts of Santa Inês Lambs. In: 1st Minas Gerais Sheep Meeting, Lavras, MG, Proceedings. Lavras; 2000. p.149168.

5. Salomoni E. Classification, typification and factors that influence carcass quality. Bagé: EMBRAPA-UEPAE (Technical Paper, 5), 1981; 44 p.

6. Oliveira NM, Osório JCS, Monteiro EM. Meat production in sheep of five genotypes. 4. Carcass and tissue composition. Ciência Rural. 1998;28:125-129.

7. Oliveira MVM, Pérez JRO, Alves EL. Evaluation of Commercial Joint, Body Components and Internal Organs of Confined Lambs and Fed with Swine Wastes. Brazilian Journal of Animal Science. 2002;31:1459-1469.

8. Garcia IFF, Perez JRO, Lima AL, et al. Allometric study on carcass tissues from purebred Santa Inês lambs or crossbred with Texel, Ile de France and Bergamácia. Brazilian Journal of Animal Science. 2004;33:453-462.

9. Sainz RD. Evaluation of carcass and standard cuts of sheep and goats. In: International Symposium on Sheep and Goats, 1st, Proceedings; 2000. p. $237-250$.

10. Müller OR, Osório FHS, Silva PM. Early weaning of lambs grazing on winter cycle cultivated pasture. The Institute of Zootechnical Research Technical Yearbook, Porto Alegre. 1973;1:43-52.

11. Manera DB, Voltolini TV, Dos AS, et al. Desempenho produtivo e características de carcaça de cabritos alimentados com diferentes proporções de concentrado. Revista Caatinga, Mossoró, 2009;22(4):240245 .

12. Reis W, Jobim CC, Macedo FAF, et al. Performance of feedlot lambs fed high-moisture grain corn silage or reconstituted grain corn silage in replacement of dry corn grain in the diet. Brazilian Journal of Animal Science. 2001;30(2):596-603.

13. Alves KS, Carvalho FR, Ferreira MA, et al. Dietary Energy Levels for Santa Inês Sheep: Carcass Characteristics and Body Constituents. Brazilian Journal of Animal Science. 2003;32(6):1927-1936.

14. Gonzaga Neto S, Silva Sobrinho AG, Resende KT, et al. Body composition and nutritional requirements of macrominerals for Morada Nova sheep. Brazilian Journal of Animal Science. 2005;34(6):2133-2142.

15. Sousa WH, De E, De A, et al. Morphometric and carcass characteristics of kid goats and lambs finished in feedlots. Brazilian Journal of Animal Science. 2009;38(7). 